\title{
Kansainvälisyyden muuttuvat merkitykset
}

$\mathrm{T}$ ämän lehden numeroon on pyritty kokoamaan toimitukselle kertyneistä aineistoista aikuiskasvatuksen kansainvälisyyttä painottavia kirjoituksia. Ehkä ne keskustelun ohella innostavat myös valmistelemaan puheenvuoroja kansaa ja kansalaisuutta perusteellisemmin käsittelevään teemanumeroon, jonka toivomme ilmestyvän ensi vuonna.

$\mathrm{T}$ oisen maailmansodan jälkeinen kansallisvaltioiden ja niiden kansalaisten väliseen rauhanomaiseen rinnakkainoloon tähtäävä kansainvälisyyden käsite on jo vuosia sitten käynyt vanhentuneeksi. Ihmiskunnan ja maapallon jako yhteiskuntajärjestelmien ja ideologioiden perusteella näyttää kadonneen, taloudet ja markkinat ovat ylikansallistuneet, pääomien ja tavaroiden ohella ihmisten pitäisi olla liikkuvia ja joustavia tuottaja-kuluttajia. "Rauha, ystävyys, solidaarisuus" -kansainvälisyys on vaivihkaa korvattu vetävämmillä monikulttuurisuuden, globalisaation tai sen vastustamisen sanastoilla. Olisiko kansainvälisyys-termi aika haudata myös aikuiskasvatuksessa ja sen tutkimuksessa? Paradoksaalisesti meille tuntuu silti edelleen olevan tärkeää, että saamme "kansainvälistä" tunnustusta ja hyväksyntää suomalaisina, taloudessa, urheilussa tai vaikkapa koulusaavutuksissa. Aikuiskoulutuksessa kansainvälistytään myös kovaa kyytiä, kohotetaan yksilöiden, yritysten ja oppilaitosten tuloskuntoa opettaja- ja opiskelijavaihdoin ja kansainvälisin kehittämisprojektein. Ja aikuiskasvatuksen tutkijoiden paine saada "kansainvälistä julkisuutta" eli lähinnä angloamerikkalaisen tiedemaailman hyväksyntä englanninkielisille tuotoksilleen kasvaa kasvamistaan, samalla kun uudet "kansainväliset" asiantuntijamarkkinat kutsuvat ylikansallisen politiikanteon palvelukseen.

$\mathrm{M}$ aailmassa on viime kuukausina tapahtunut asioita, joista aikuiskasvatuksessakaan tuskin voi pidemmän päälle vaieta. Syyskuinen terrori-isku Yhdysvaltoihin nostatti uuden uskonnollisilla ja kulttuurieroilla perustellun jaon ihmisten ja kansallisvaltioiden keskelle ja hiukan aikaa sitten kurdinaisen "kunniamurha" kyseenalaisti Ruotsissa omaksuttujen monikulttuurisuusperiaatteiden oikeellisuuden. Lisäksi suomalaisten lasten ja nuorten lisääntynyt henkinen pahoinvointi ja väkivaltaisuus ovat nostaneet esiin aikuisuuden ja vanhemmuuden merkityksen yhteiskunnassa. Kaikki nämä tapahtumat kuuluvat monimutkaisiin yhteiskunnallis-historiallisiin kehityskulkuihin, joiden ymmärtämisessä ja arvottamisessa yksittäinen ihminen voi tuntea voimattomuutta. Oletan, että näiden kansainvälisyyden muuttuvien ja ristiriitaisten merkitysten pohdinta johtaa aikuiskasvattajatkin väistämättä kasvatuksen eettisiin peruskysymyksiin. Globaalien markkinoiden arvot vaativat 
joustavuutta, muutosvalmiutta, yrittäjyyttä ja itseohjautuvuutta, joiden kääntöpuolena on elämän lisääntyvä ennakoimattomuus ja epävarmuus.

1 istä kansainvälisyyden muuttuvia merkityksiä pohtiva etiikka voisi vismiin tai rationalistis-postkonventionaalisiin arvoihin perustuva diskursiivinen tai kommunikatiivinen etiikka, joka kuitenkin väistämättä ehdollistuu kulttuurisesti ja kansallisvaltiollisesti. Voiko sellainen etiikka mitenkään universaalisti käsitellä sellaisia "kansainvälisiä" ongelmia kuin ihmisten eksistentiaalinen turvattomuus ja epäluottamus ja niistä kehkeytyvä itseen tai muihin kohdistuva pelko, viha ja tuhoavuus? Tarvittaisiinko täydentävää tai vaihtoehtoista ei-diskurssiivista tai esidiskursiivista etiikkaa, joka etsisi - ainakin ihmislajille - universaaleja arvoja yhtäältä emotionaalis-aistimellisesta "toiselle" vastaamisesta, toisaalta ihmisen luontoon uponneisuudesta. Esitietoinen oppiminen toisen - ja/tai luonnon - elämänhalun itselle asettamista rajoista, toisen tarvitsevuuteen ja heikkouteen vastaamisesta saattaa olla välttämätön ja vähin ehto ihmisen eettisyyden planetaarisille muodoille ja ihmislajin elämän planetaariselle jatkumiselle. Siihen kuuluisi samalla sen oppimista, että oma tarvitsevuus ja elämänhalu ovat toisen ja luonnon vastaamisesta riippuvaisia. Askelmat ihmisten välisistä kohtaamisista turvallisuus- ja talouspolitiikkaan vaikuttamiseen ovat toki pitkät ja mutkikkaat, mutta elleivät aikuiskasvattajat kanna huolta niiden rakentumisesta, ketkä sitten?

Tämän numeron kirjoittajat johdattavat pohtimaan joitakin kansainvälisyyden muuttuvista merkityksistä puheenvuoroillaan aikuiskasvatuksen todellisuuksista, haasteista ja haaveista, niin kansallisesti ja kulttuurisesti rajatuilta paikoiltaan kuin globaalistakin näkökulmasta.

Anja Heikkinen

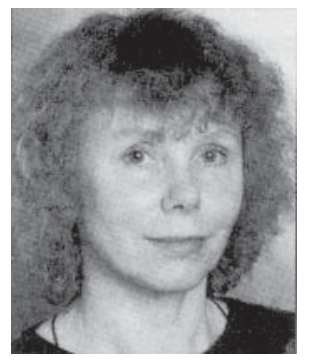

